\title{
EU COHESION POLICY POST-2020, EUROPEAN GREEN DEAL AND TERRITORIAL AGENDA 2030. THE FUTURE OF THE PLACE-BASED APPROACH IN THE NEW EU POLICY FRAMEWORK IN THE CONTEXT OF COVID-19
}

\author{
Paulo Neto iD \\ Department of Economics, UMPP - Public Policy Monitoring Unit, CICS.NOVA - Interdisciplinary Centre of \\ Social Sciences, CIES-ISCTE - Centre for Research and Studies in Sociology, CEFAGE-UÉ - Center for Advanced \\ Studies in Management and Economics, University of Évora \\ Largo dos Colegiais 2, 7000-Évora: Portugal \\ neto@uevora.pt
}

\begin{abstract}
The European Union's strategic priorities for the post-2020 period - focused on areas such as globalization, demography, migration, climate change, security and defense, employment and digitalization of the economy and society - pose relevant challenges as to the feasibility of its territorialization conditions and how to ensure operationalization at regional and local levels. As the EU prepares to implement the Cohesion Policy 2021-2027 and draw up the Territorial Agenda 2030, it also seeks to relaunch the EU policy framework in areas such as sustainable development, artificial intelligence and reindustrialization, examples of which are: European Green Deal, EU Circular Economy Action Plan and EU Digital Strategy. The current context of the COVID-19 pandemic has, however, forced a refocusing of the intervention priorities, at least in the short term, in the need to respond to the urgent economic, social and public health challenges caused by the pandemic. This article seeks to analyse, on the one hand, how the European policy cycle has adapted to respond to the pandemic, and on the other, the extent to which the place-based approach, one of the central operating rationales of the 2014-2020 financial perspective, may see its role strengthened and its performance extended as a consequence of the changes introduced in the current phase of the policy cycle due to the COVID-19 pandemic. The analysis carried out led to concluding that the current context of COVID-19 is implying the redesign of many of the Union's public policy instruments and reordering some of the current strategic priorities. It is also changing the conditions of resilience and competitiveness of territories, whereby the place-based approach seems to be a public policy instrument especially suited to the process of economic and social recovery at the local and regional level.
\end{abstract}

Keywords: COVID-19 pandemic, EU Cohesion Policy, EU policy framework post 2020, place-based approach.

\section{Introduction}

The European Union's (EU) strategic priorities for the post-2020 period - focused on areas such as globalization, demography, migration, climate change, security and defense, employment and digitalization of the economy and society - pose relevant challenges as to the feasibility of its territorialization conditions and how to ensure operationalization at regional and local levels. As the EU prepares to implement the Cohesion Policy 2021-2027 (CP) and draw up the Territorial Agenda 2030 (TA2030, 2020), it also seeks to relaunch the EU policy framework in areas such 
as sustainable development, artificial intelligence and reindustrialization, examples of which are: European Green Deal (EC, 2019a), EU Circular Economy Action Plan (EC, 2020a) and EU Digital Strategy (EC, 2018).

However, the current pandemic context of COVID-19 appears to be causing profound changes in essential elements of the EU Policy mainframe, which until January 2020 were taken for granted, and around which strategic orientations for the EU until 2030 were being prepared. Indeed, due to the COVID-19 pandemic, and public health and civil protection challenges, but also in terms of the resulting consequences for the economy, employment and social mobility, many of the strategic priorities defined for the EU at the end of 2019 are now being reformulated and adapted to the new context. Therefore, it is extremely relevant to analyze the extent to which the COVID-19 pandemic is reformulating and re-hierarchizing the public policy priorities of the Union and consequently, reordering the relative position of some current development objectives and some of their relevant parent policies such as the $\mathrm{CP}$.

On this issue, the OECD (2020a) defends the importance of adopting a place-based, or territorially sensitive, approach to support the definition of exit-strategy implementation and recovery policies from the COVID-19 pandemic. As McCann and Ortega-Argilés underlined:

[f]ollowing the place-based logic, the fostering of development is to be achieved by aligning and coordinating the funding and design of policy interventions between the local, regional, national and EU levels of governance in ways which maximises the 'bottom-up' engagement and mobilisation of local actors and stakeholders in the policy process (2016, p. 287).

From this perspective, this article seeks to analyze the extent to which the place-based approach, one of the central operating rationales of CP 2014-2020, may see its role strengthened and its performance extended as a consequence of the changes introduced in the current phase of the EU's policy cycle due to the COVID-19 pandemic.

In addition, taking into account that the current pandemic context has revealed different territorial (local and regional) performances in the different EU member states - and many of the containment measures have been established based on municipal and regional incidence indicators - it is also relevant to analyze the extent to which the place-based approach may play an important role, as an instrument of public policy, in the context of the COVID-19 pandemic.

To achieve these objectives, this article is structured in eight main sections. After the Introduction, the second and third sections are devoted to reviewing the literature on the place-based approach, and presenting the methodological approach adopted. In the fourth section, the EU policy framework before the pandemic will be detailed and analyzed. Sections five and six will study how, since March 2020, the COVID-19 pandemic has become central to policy and how it has determined a process of rethinking policy options. The seventh section will focus on discussing the future of the EU's place-based approach, in the light of the policy guidelines in CP 2021-2027 and the new developments arising from COVID-19. Section eight concludes and gives some policy recommendations.

\section{Literature review}

The place-based approach to socio-economic development policies 'stresses its intentional focus on three features: the place-specificity of natural and institutional resources and of individual preferences and knowledge; the role played by the (material and immaterial) linkages between places; and the resulting need for interventions to be tailored to places' (Barca, 2009, p. 4). 
A place-based development policy can therefore be defined as (Barca, 2009, p. 5):

(i) [a] long-term development strategy whose objective is to reduce persistent inefficiency (underutilisation of the full potential) and inequality (share of people below a given standard of well-being and/or extent of interpersonal disparities) in specific places; (ii) [t]hrough the production of bundles of integrated, place-tailored public goods and services, designed and implemented by eliciting and aggregating local preferences and knowledge through participatory political institutions, and by establishing linkages with other places; and (iii) [p] romoted from outside the place by a system of multilevel governance where grants subject to conditionalities on both objectives and institutions are transferred from higher to lower levels of government.

The place-based approach goes beyond the trends related to the adopted ways of territorial governance (centralization or decentralization of policies); ' $[t]$ he responsibility for policy design and implementation is allocated among different levels of government supported by both contractual relations and trust, with a role being played by special-purpose institutions (agencies, public-private partnerships, etc.)' (Barca, 2009, XI).

Tomaney (2010, p. 6) draws attention to:

(...) the identification and mobilization of endogenous potential, that is, the ability of places to grow drawing on their own resources, notably their human capital and innovative capacities. This approach aims to develop locally-owned strategies that can tap into unused economic potential in all regions and are the basis for strategies that tackle questions of sustainable development and human wellbeing. Such approaches require strong and adaptable local institutions, such as regional development agencies, which are increasingly commonplace around the world. At the same time, such approaches require the involvement of awide range of stakeholders and mechanisms for identifying assets in the local economy that can be the basis for local growth strategies.

According to Barca, McCann and Rodríguez-Pose (2012, p. 139) this approach takes that:

(...) geographical context really matters, whereby context here is understood in terms of its social, cultural, and institutional characteristics. As such, a space-neutral sectoral approach is (...) as inappropriate; what are apparently space-neutral policies will always have explicit spatial effects, many of which will undermine the aims of the policy itself unless its spatial effects are explicitly taken into consideration.

For Bentley and Puglis (2014, p. 283) place-based thinking reflects the continual search for solutions to address territorial, social and economic inequalities and development capacities. Whether it provides a workable policy solution will be contingent on a number of factors, not least spatial context in terms of social, cultural, economic and institutional characteristics. Reflecting the multiplicity of places, place-based approaches, in raising questions about the relationship between scales of operation and institutional structures, are a subset of broader debates and issues concerning not only what works but also where.

Many of the studies carried out in recent years on the place-based approach applied to the processes of economic and social development focus especially on three major categories. On the one hand, studies that focus on analyzing the application of this approach to specific local and regional territories, such as Glaeser and Gottlieb (2008), Celata and Coletti (2014), Neumark and Simpson (2015), Guastella and Timpano (2016), Horlings, Roep and Wellbrock (2018), Jia, Ma, Qin and Wang (2020). 
On the other, those that focus on the perspective of assessing the impacts and effects of applying place-based development strategies. This is the case, among others, of Partridge, Rickman, Rose Olfert and Tan (2013), Varga (2017), Magro and Wilson (2019), Blomi and Erlich (2020). Finally, studies that analyze the particular case of the application of specific public policy instruments aimed at the implementation of place-based policies - such as the regional smart specialisation strategies - and where the work of, among others, Neto, Serrano and Santos (2018), Gianelle, Guzzo and Mieszkowski (2020), Gianelle, Kyriakou, McCann and Morgan (2020), Neto and Santos (2020), Trippl, Zukauskaite and Healy (2020), Veldhuizen (2020), is contained.

This article seeks to carry out a separate analysis and focuses on examining how the placebased nature of local and regional approaches is present, and is promoted by the policies of the EU - in particular, but not only, its CP - and also analyses the extent to which the COVID-19 pandemic is refurbishing the EU's options in terms of a place-based approach.

The option for this perspective is due to the place-based approach being one of the fundamental objectives underlying rational implementation of the EU's CP 2014-2020 and it will continue to be a focus of public policy in the CP 2021-2027, or at least that was the belief before the start of the COVID-19 pandemic.

\section{Methodological approach}

This article studies the decision-making process of the institutions of the EU, focusing on analysis of the different official EU documents that formalize these decision-making procedures as well as on the official acts of communicating the decisions taken. From a methodological point of view, a content analysis methodology was adopted.

Regarding the official EU documents that were the object of this analysis, they were grouped in two categories, namely: (i) official EU documents published until January 31, 2020, that is, deliberations and strategic guidelines adopted in the pre-pandemic period, and (ii) official Union documents published between 1 February and 31 July 2020, in order to analyze, from the perspective referred to in the previous point, the EU's reaction during the first wave of the COVID-19 pandemic.

\section{EU policy framework before the pandemic}

In the report 'A Union that strives for more. My agenda for Europe. Political Guidelines for the Next European Commission 2019-2024' (von der Leyen, 2019), as well in the speech by President-elect Ursula von der Leyen in the European Parliament Plenary on the occasion of the presentation of her College of Commissioners and their programme (von der Leyen, 2019, November 27), the new President of the European Commission proposed the Political guidelines for the EU, over the next five years and well beyond, focusing on six headline ambitions for Europe, namely: (i) A European Green Deal; (ii) an economy that works for people; (iii) a Europe fit for the digital age; (iv) protecting European way of life; (v) a stronger Europe in the world, and (vi) a new push for European democracy.

Over the past few years the EU has been consolidating the EU CP's policy cycle around nine essential aspects (Neto, 2020ab): (i) from a policy focused on correcting regional disparities to a policy applied across the Union; (ii) from a policy focused on supporting the achievement of 
national and regional objectives to a policy geared towards the realization of European designs; (iii) from the valuation of mono or inter-sectoral and single policy approaches and strategies, to the option of cross-sectoral and trans-policy approaches and strategies; (iv) a stronger link with the European Semester and the Union's economic governance; (v) growing concern about the territorialization of impacts and results; (vi) strengthening the interaction between the $\mathrm{CP}$ and other EU policy instruments, more specifically the Common Agricultural Policy, the Horizon Europe, LIFE, Erasmus +, Digital Europe, the Connecting Europe Facility and the InvestEU fund; (vii) the CP embraces the EU's new strategic priorities until 2030 and distances itself from the classic rationale of regional development policies; (viii) budgetary allocation for the CP now supports new, traditionally 'non-regional' areas, and (ix) the Research and Innovation Strategies for Smart Specialisation (RIS3), as an instrument of public policy, gain relevance.

The EU policy framework in 2019 had as its main guiding documents the results already achieved up to that point with regard to CP 2021-2027, the already very advanced negotiations in the new multiannual financial framework, and a set of programmatic documents to define the future policies of the Union. Among them, the EU Territorial Agenda 2030, the EU Circular Economy Action Plan, the EU Digital Strategy and the European commitment to achieving the Sustainable Development Goals of the United Nations Agenda 2030 stand out (Table 1).

Table 1. The framework of EU policies with major territorial relevance before the pandemic

\begin{tabular}{|c|c|c|c|}
\hline $\begin{array}{c}\text { EU Cohesion Policy } \\
2021-2027\end{array}$ & $\begin{array}{l}\text { EU Territorial Agenda } \\
2030\end{array}$ & $\begin{array}{c}\text { EU Digital Strategy } \\
2019-2024\end{array}$ & $\begin{array}{l}\text { EU Circular Economy } \\
\text { Action Plan }\end{array}$ \\
\hline $\begin{array}{l}\text { A focus on five investment } \\
\text { priorities: } \\
\text { - Smarter Europe; } \\
\text { - A Greener, carbon free } \\
\text { Europe; } \\
\text { - A more Connected } \\
\text { Europe; } \\
\text { - A more Social Europe; } \\
\text { - A Europe closer to } \\
\text { citizens; } \\
\text { - A more tailored } \\
\text { approach to regional } \\
\text { development. }\end{array}$ & $\begin{array}{l}\text { The actions aim to } \\
\text { strengthen: } \\
\text { - Multi-level governance; } \\
\text { - Coordination of sector } \\
\text { policies in terms of their } \\
\text { territorial impacts and } \\
\text { coherence; } \\
\text { - Cooperation between } \\
\text { territories; } \\
\text {-Territorial cohesion at } \\
\text { European level; } \\
\text { - Territorial cohesion } \\
\text { at cross-border, } \\
\text { transnational, inter- and } \\
\text { intraregional level; } \\
\text { - member state } \\
\text { and neighbouring } \\
\text { countries'contributions to } \\
\text { territorial cohesion. }\end{array}$ & $\begin{array}{l}\text { Policy areas: } \\
\text { - Data protection; } \\
\text { - Better access to online } \\
\text { goods for consumers and } \\
\text { businesses; } \\
\text { - The right environment } \\
\text { for digital networks and } \\
\text { services; } \\
\text { - Economy and Society; } \\
\text { - European Data Strategy. }\end{array}$ & $\begin{array}{l}\text { The new Circular Economy } \\
\text { Action presents measures } \\
\text { to: } \\
\text { - Make sustainable } \\
\text { products the norm in the } \\
\text { EU; } \\
\text { - Empower consumers } \\
\text { and public buyers; } \\
\text { - Focus on the sectors } \\
\text { that use most resources } \\
\text { and with the potential for } \\
\text { circularity; } \\
\text { - Ensure less waste; } \\
\text { - Make circularity work } \\
\text { for people, regions and } \\
\text { cities, } \\
\text { - Lead global efforts on } \\
\text { circular economy. }\end{array}$ \\
\hline
\end{tabular}

Source: author's own elaboration based on CEAP (2020), DS2019-2024 (2020), EC (2020f) and TA2030A (2020).

In the specific case of the Territorial Agenda 2030', its implementation process will rely 'on informal multilevel cooperation between member states, sub-national authorities, the European Commission, European Parliament, the European Committee of the Regions and the European Economic and Social Committee, the European Investment Bank and other relevant players [... and ...] would benefit from cooperation with those in charge of the Urban Agenda, the New Leipzig harter

\footnotetext{
1 Set up in 2018 during the Austrian Presidency, an intergovernmental taskforce is currently leading the work on the renewal of the territorial agenda, the aim being to conclude the process under the German Presidency, with the signing of a 2030 territorial agenda in December 2020. See https://www.europarl.europa.eu/RegData/etudes/ BRIE/2020/649355/EPRS_BRI(2020)649355_EN.pdf .
} 
and EU Cohesion and Rural Development Policy, and the EU macro-regional and sea basin strategies.' (TA2030A, 2020).

The report Setting the Course for the future of Territorial and Urban Policies at European level (AP, 2018) proposed a set of principles that should underpin the definition of future EU territorial policies, by reinforcing the role of governance as a key element of territorial cohesion. Namely, because: (i) territorial policies at the European level rely on a soft policy approach; (ii) soft policy systems need innovative approaches to achieve different targets for different places; (iii) placebased approaches require tailor-made governance mechanisms, because form should follow function.

Through the EU Digital Strategy 2019-2024 (EU, 2019), the EU aspires to shape Europe's digital future based on four main pillars of action (EDS, 2020): (i) technology that works for people; (ii) a fair and competitive digital economy; (iii) an open, democratic and sustainable digital society.

The EU Circular Economy Action Plan (EC, 2020a, p. 2-3) aims to provide 'a future-oriented agenda for achieving a cleaner and more competitive Europe in co-creation with economic actors, consumers, citizens and civil society organisations (...) set of interrelated initiatives to establish a strong and coherent product policy framework that will make sustainable products, services and business models the norm and transform consumption patterns so that no waste is produced in the first place'.

As mentioned in the EU Annual Sustainable Growth Strategy 2020 the EU aspired to affirm the EU's economy as 'an economy that works for people and planet' (EC, 2019b, p. 5). In this sense, at the end of 2019, the European Green Deal was the new growth strategy - and competitive sustainability the proposed new development paradigm - for the EU which 'puts sustainability - in all of its senses - and the well-being of citizens at the centre of our action. This requires bringing together four dimensions: environment, productivity, stability and fairness [in order to] transform the Union into a sustainable economy, helping the EU and its member states to achieve the United Nations Sustainable Development Goals, which they committed to' (EC, 2019b, p. 2).

The European Green Deal (EC, 2019a) will be based on the following set of operating principles: (i) transforming the EU's economy for a sustainable future, designing a set of deeply transformative policies; (ii) increasing the EU's climate ambition for 2030 and 2050; (iii) supplying clean, affordable and secure energy; (iv) mobilising industry for a clean and circular economy; (v) building and renovating in an energy and resource-efficient way; (vi) accelerating the shift to sustainable and smart mobility; (vii) 'From Farm to Fork': designing a fair, healthy and environmentally-friendly food system; (viii) preserving and restoring ecosystems and biodiversity; (ix) a zero pollution ambition for a toxic-free environment; $(x)$ mainstreaming sustainability in all EU policies; (xi) pursuing green finance and investment and ensuring a just transition; (xii) greening national budgets and sending the right price signals; (xiii) mobilising research and fostering innovation; (xiv) activating education and training; ( $\mathrm{xv}$ ) a green oath: 'do no harm'.

The European Commission is thus banking on the transformative power that the European Green Deal will be able to achieve as a result of the twin digital and climate transitions that it aims to promote, and the resulting potential to strengthen its own industrial base and innovation potential.

In close conjunction with the EU European Green Deal, the European Commission established the launch for March 2020 of the European Climate Pact ${ }^{2}$, with the following three objectives: (i) to encourage information sharing, inspiration, and foster public understanding of the threat and challenge of climate change and environmental degradation and how to counter it; (ii) to create

\footnotetext{
${ }^{2}$ Open public consultation of the EU European Climate Pact ended on 17 June 2020. See https://ec.europa.eu/ clima/news/shaping-european-climate-pact-commission-launches-public-consultation_en .
} 
real and virtual spaces for people to express their ideas and creativity and work together on ambitious action, at both the individual and collective level; (iii) to work on building capacity to facilitate grassroots initiatives on climate change andenvironmental protection.

Until the beginning of 2020, one of the central elements of the EU policy framework was also the EU's commitment to meeting the Sustainable Development Goals defined by the United Nations Agenda 2030, adopted in September 2015. The report Sustainable development in the European Union Monitoring report on progress towards the SDGs in an EU context (Eurostat, 2020) clearly demonstrates the efforts of the $\mathrm{EU}$ and its member states to realize their commitment to the Agenda 2030 Sustainable Development Goals.

And despite the relative failure to comply with several of the 17 Sustainable Development Goals, according to this report 'the EU has made strong progress towards fostering peace and personal security, access to justice as well as trust in institutions (SDG 16) (...) good progress over the past five years was visible in reducing certain aspects of poverty (SDG 1) and in improving the health situation of the EU population (SDG 3). The advances in these areas have also helped to increase the quality of life in cities and communities (SDG 11)' (Eurostat, 2020, p. 10-12). Improvements lay in the labour market (SDG 8) and in the viability and sustainability of the EU's agriculture sector (SDG 2), 'although some of its environmental impacts have further intensified' (Eurostat, 2020, p. 12).

In 2020, the Sustainable Development Goals were also obligatorily reflected in the European Semester (Spring Package) country reports and the communication accompanying the country-specific recommendations (EC, 2020bc). Until March 2020, this set of policy instruments, and guiding documents, formed the essential elements of the strategic and political framework with which the EU proposed to lead Europe until 2030.

\section{The pandemic moved to the center of EU policies}

Following the declaration by the World Health Organization on the COVID-19 pandemic, on March 13, 2020, the pandemic became central to policy at the EU level and progressively also worldwide.

Since the beginning of the COVID-19 pandemic crisis, 'many [EU] Member States have implemented national targeted measures and participated to several EU-coordinated initiatives to counteract the adverse effects of the lockdown' (Conte, Lecca, Sakkas \& Salotii, 2020, p. 1).

From March 2020 until the time of writing, the EU has launched a wide range of initiatives to tackle the pandemic, mainly through two complementary channels. Mainly, through creating a new set of initiatives aimed specifically at resolving and or mitigating the effects of the pandemic in terms of public health, but also the resulting economic and social effects. In addition, by mobilizing a set of policies and public policy instruments to combat the effects of the pandemic, with the purpose of allocating resources to the new needs of the European economy and society.

Among the set of new EU initiatives created specifically to deal with the pandemic, the following stand out: (i) The EU Recovery Plan for Europe; (ii) The SURE / ESM Pandemic Crisis Support / EIB Guarantee Fund for Workers and Businesses; (iii) The Next Generation EU policy instrument; (iv) The Re-open EU initiative; (v) The European roadmap to lifting coronavirus containment measures; (vi) The initiative EUvsVirus Challenge; (vii) The European Skills Agenda for sustainable competitiveness, social fairness and resilience, and (viii) Temporary State Aid rules (Table 2). 
Table 2. Main objectives of the new EU initiatives created specifically to deal with COVID-19 and the coronavirus pandemic

\begin{tabular}{|c|c|}
\hline Instruments & Objectives \\
\hline EU Recovery Plan for Europe & $\begin{array}{l}\text { - The new Multiannual Financial Framework (MFF) will cover seven years } \\
\text { between } 2021 \text { and } 2027 \text {. The MFF, reinforced by Next Generation EU, will } \\
\text { also be the main instrument for implementing the recovery package to } \\
\text { tackle the socio-economic consequences of the COVID-19 pandemic; } \\
\text { - The MFF will cover the following spending areas: (i) Single market, } \\
\text { innovation and digital; (ii) Cohesion, resilience and values; (iii) Natural } \\
\text { resources and the environment; (iv) Migration and border management; } \\
\text { (iv) Security and defence; (v) Neighbourhood and the world; (vi)Europe- } \\
\text { an public administration. }\end{array}$ \\
\hline $\begin{array}{l}\text { The SURE / ESM Pandemic Crisis } \\
\text { Support / EIB Guarantee Fund for } \\
\text { Workers and Businesses }\end{array}$ & $\begin{array}{l}\text { - Pandemic Crisis Support based on Enhanced Conditions Credit Line } \\
\text { (ECCL); } \\
\text { - Liquidity support to help hard-hit small and medium-sized enterprises } \\
\text { with an emergency support package; } \\
\text { - Funding to member states of up to } € 100 \text { billion by covering part of the } \\
\text { costs related to the creation or extension of national short-time work } \\
\text { schemes. }\end{array}$ \\
\hline The Next Generation EU & $\begin{array}{l}\text { - Support for member states with investments and reforms; } \\
\text { - Kick-starting the EU economy by incentivising private investments; } \\
\text { - The amounts will be allocated to seven individual programmes: (i) Re- } \\
\text { covery and Resilience Facility (RFF); (ii) ReactEU; (iii) Horizon Europe; (iv) } \\
\text { InvestEU; (v) Rural Development; (vi) Just Transition Fund; (vii) RescEU. }\end{array}$ \\
\hline The Re-open EU initiative & $\begin{array}{l}\text { - To respond to doubts regarding safe travel in member countries; } \\
\text { - A web platform to promote a safe recovery of travel and tourism in all } \\
\text { European countries; } \\
\text { - Protect public health and also the possibility of being able to go on } \\
\text { vacation, travel, get closer to family and friends with a safe reopening of } \\
\text { European borders. }\end{array}$ \\
\hline $\begin{array}{l}\text { The European roadmap to lifting } \\
\text { coronavirus containment measures }\end{array}$ & $\begin{array}{l}\text { - European roadmap towards lifting coronavirus containment measures; } \\
\text {--Takes into account the expertise of the European Centre for Disease } \\
\text { Prevention and Control, the Commission's Advisory Panel on Coronavi- } \\
\text { rus, experience of member states and guidance from the World Health } \\
\text { Organization. }\end{array}$ \\
\hline The initiative EUvsVirus Challenge & $\begin{array}{l}\text { - Connect the needs of innovators with the opportunities made available } \\
\text { by investors, corporations, public authorities, academia and research } \\
\text { institutions; } \\
\text { - Promote secure deals and funding to support scale up of innovative } \\
\text { solutions and bring them to the market; } \\
\text { - Address relevant COVID-19 challenges and innovative soluctions to } \\
\text { speed up European and global recovery in the aftermath of the pandem- } \\
\text { ic. }\end{array}$ \\
\hline $\begin{array}{l}\text { The European Skills Agenda for } \\
\text { sustainable competitiveness, social } \\
\text { fairness and resilience }\end{array}$ & $\begin{array}{l}\text { - Create a Pact for Skills; } \\
\text { - Strengthening skills intelligence; } \\
\text { - Develop EU support for strategic national upskilling action; } \\
\text { - Promote rolling out of the European universities' initiative and upskill- } \\
\text { ing scientists; } \\
\text { - Develop skills to support green and digital transitions. }\end{array}$ \\
\hline
\end{tabular}

Source: author's own elaboration based on Council (2020), EC (2020fghi), ESM (2020) and EU (2020).

The aforementioned set of public policy initiatives created specifically by the EU to tackle the pandemic, the global COVID-19 context, also implied significant adjustments to the Union's main policies. Since March 2020, the EU has been introducing a series of changes and adjustments to the $\mathrm{CP}$ with a view to its mobilization to combat coronavirus.

In the CP context, the European Commission launched two packages of measures (EC, 2020mn): (i) The Coronavirus Response Investment Initiative (CRII) and the Coronavirus Response Investment 
Initiative Plus (CRII+). These measures mobilise the $\mathrm{CP}$ to respond flexibly to rapidly emerging needs in the most exposed sectors, such as healthcare, small and medium enterprises and labour markets, and help the most affected territories in member states and their citizens, including new methods to reach the most vulnerable through the Fund for European Aid to the Most Deprived (EC, 2020l).

The European Commission made a series of proposals (CRII package) on 13 March 2020 to amend legislation that will allow Member States to benefit from more financial back-up and targeted assistance. The European Parliament voted almost unanimously in favour of the Commission proposals on 26 March. The Council finally adopted the package on 30 March 2020, which entered into force on 1 April 2020.On 2 April the Commission proposed a new set of exceptional measures introducing extraordinary flexibility and simplification, support for the most deprived and for the fishing industry - the Coronavirus Response Investment Initiative Plus (CRII+). This new package was adopted by the European Parliament on 17 April and is currently under discussion at the Council (EC, 2020j).

Given the significant social implications of the pandemic, particularly in terms of employment, a good example of the adjustments the EU is introducing to its policies is associated with implementation of the European Pillar of Social Rights and the way in which the European Social Fund (2014-2020) and the European Social Fund Plus (2021-2027) operate. In this area, the main adjustments are as follows (EC, 2020d): (i) significant additional resources for the European Social Fund (ESF) and Fund for European Aid to the most Deprived (FEAD); (ii) a strengthened European Social Fund Plus proposal; (iii) a reinforced European Globalisation Adjustment Fund (EGF); and (iv) additional funds supporting employment and social objectives, namely through reinforcing the Just Transition Fund - closely related to the European Green Deal - and the InvestEU 2021-2027 and the Erasmus programs.

Even within the framework of the European Semester (Spring Package), published on May 20, 2020, the European Commission has proposed country-specific recommendations providing economic policy guidance to all EU member states in the context of the coronavirus pandemic, focused on the most urgent challenges and on relaunching sustainable growth (EC, 2020c). Therefore, the coronavirus pandemic forced a refocusing of the European Semester (Spring Package), especially on issues related to the European strategy of competitive sustainability - stability, fairness, environmental sustainability and competitiveness - particularly associated with the effects of the pandemic and placing a special emphasis on health issues.

Ciampi Stancova (2020) analyzed how the Next Generation EU initiative, created specifically to combat the economic and social effects of the COVID-19 pandemic and to prepare for the economic recovery of the EU and its different member states, will be articulated in 2021 and 2022 with the EU's CP, European Green Agreement, the European Semester and the European strategy in the field of smart specialisation, which is, by its nature, a place-based approach.

In the EU, the pandemic also determined new recognition of the need for a new centrality of health and civil protection policies through: (i) a new Health Program, EU4Health, to strengthen health security and prepare for future health crises; (ii) the reinforcement of rescEU, the Union's Civil Protection Mechanism, which will be expanded and strengthened to equip the EU to prepare for and respond to future crises; (iii) budgetary reinforcement of Horizon Europe to support vital research in health, resilience and the green and digital transitions (EC, 2020k).

On 1 July 2020, the European Commission presented the European Skills Agenda for sustainable competitiveness, social fairness and resilience (EC, 2020i). This sets ambitious, quantitative objectives for upskilling (improving existing skills) and reskilling (training in new skills) to be achieved within the next 5 years. Its 12 actions focus on skills for jobs by partnering up with member states, 
companies and social partners to work together for change, by empowering people to embark on lifelong learning, and by using the EU budget as a catalyst to unlock public and private investment in people's skills, and whose proposals are naturally not unconnected to the current pandemic context.

Moreover, the European Council, 19 June 2020, and the Special European Council, 17-21 July 2020, were entirely devoted to discussing the recovery plan to respond to the COVID-19 crisis and a new long-term EU budget. In the Special European Council Meeting, 17-21 July 2020, EU leaders agreed a recovery package and the 2021-2027 budget, which will help the EU to rebuild after the pandemic and support investment in green and digital transitions (ECouncil, 2020).

At a global scale, the EU is also envolved in the Coronavirus Global Response building on the commitment made by G20 leaders on 26 March 2020 to present a united front against the pandemic. With this in mind, on 24 April, the World Health Organization and a group of global actors called for collaboration in accelerating the development, production and equitable access to coronavirus tools ${ }^{3}$.

\section{Rethinking policy options}

In 1987, Logan and Molotch published Urban Futures: The political economy of place, with a sociological, but also political and economic perspective, describing the formative process creating contemporary American cities.

Neto (1999, p. 238) in Spatial Integration, Network Economies and Innovation, proposed 'the development of a political economy for local and regional spaces that would provide a new model for the definition of economic policy (regional policy included) in the European Union, through the implementation of a debate and a broad reflection that would take shape, including the future progressive affirmation of a political economy of European integration'.

Concerning policy options, Morgan and Jones (2019) argue that 'we need a cognitive shift in our thinking about what constitutes place-based development (...) a key part of this cognitive shift is to view and value the Foundational Economy anew by appreciating the role that FE [Foundational Economy] sectors - like care, health, education, food, energy, water and affordable housing, etc. - play in meeting human needs and underwriting collective wellbeing'.

The central issue which is always present in every local, regional or national context is the question of how to best design and implement development policies which are most appropriate for fostering good growth in the local setting (McCann \& Ortega-Argilés, 2016, p. 281).

At this time when the current pandemic context is raising a wide-ranging public and institutional debate at the global and EU scale 'revisiting the pros and cons of globalization' (OECD, 2020a, p. 17), and on the need for a 'shift in values and increased sense of collective destiny' (OECD, 2020a, p. 17), 're-imagining future public life' (OECD, 2020a, p. 18), the need for reflection on a new political economy for local and regional spaces and a political economy of European integration has gained new relevance.

Indeed, 'subnational governments - regions and municipalities - are responsible for critical aspects of containment measures, health care, social services, economic development and almost $60 \%$ of public investment, putting them at the frontline of crisis management. Because such responsibilities are shared among levels of government, coordinated effort is critical' (OECD, 2020b, p. 2). 'The regional and local impact of the COVID-19 crisis is highly heterogeneous, with a strong terri-

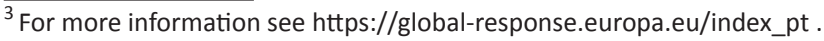


torial dimension [especially with regard to health and society, economics and public expenditure] that has important consequences for crisis managment and policy responses' (OECD, 2020b, p. 2).

In the report From Pandemic to Recovery: Local employment and economic development (OECD, 2020a), the OECD provides evidence of the importance of local action to help address the short-term and long-term consequences of the coronavirus (COVID-19) outbreak and highlights a number of areas in which the territorial impact of the pandemic will be particularly relevant. In particular, the following (OECD, 2020a, p. 3-18):

1. short-term confinement measures are likely to affect places differently depending on their areas of economic activity;

2. a key challenge for local and regional actors will be to take into account the changes brought about by the COVID-19 crisis to construct the communities of a new tomorrow;

3. trade-exposed regions are likely to face high risks;

4. greater local shares of non-standard work increase the risk of short-term job losses;

5. regional divides are already starting to show in administrative data on unemployment;

6. some of the hardest hit local economies may struggle for years to come;

7. local actions are an essential part of the recovery, from helping the disadvantaged to supporting firms or mobilising the social economy;

8. regional and local governments implement national schemes, and complement them with locally tailored responses for the short and long term;

9. local action is particularly important to help disadvantaged groups who will bear the brunt of the crisis today and in the future;

10. the social economy is increasingly called upon to address local employment needs and other areas of social impact;

11. small and medium-sized enterprises are particularly dependent on their local economies and institutions, and are important drivers of local development;

12. in the medium to long term, local action can link worker and firm needs, addressing shifts in the demand for skills and employment opportunities post-COVID-19;

13. the COVID-19 crisis will accelerate change in local development, especially an accelerated digital transition with implications for job location and access to services.

For this reason, the pandemic context has brought new relevance to local and regional scales, as spaces for defining policy, but also as spaces for solving problems that do not only concern these communities, but have national and European relevance. In view of the current pandemic, and the resulting economic and social impacts, the aspects highlighted by the OECD (2020a, p. 3-18) identified above raise the need to rethink policy options. Both in terms of how to incorporate the territorial dimension in future public policies in response to the effects and impacts of the pandemic, and in terms of taking into account the differentials of sensitivity and resilience to the effects of the pandemic in each local and regional territory.

It must be borne in mind that these local and regional differentials of sensitivity and resilience to the effects of the pandemic are largely due to factors such as: (i) nature and characteristics of the economic specialization model; (ii) type of economic sectors on which territorial economic specialization is based; (iii) technological characteristics and ways of organizing production processes; (iv) level and type of opening the economy abroad; (v) qualification level, skills and characteristics of human resources. Therefore, territorial policies matter more than ever. 


\section{The future of the place-based approach}

The COVID-19 pandemic has brought new visibility and relevance to a set of aspects that historically were part of the concerns and the theoretical and analytical body of regional economics, and of the so-called regional or territorial sciences.

In particular, aspects such as the following (OECD, 2020b): (i) multi-level coordination bodies that bring together national and subnational government representatives, in order to minimise the risk of a fragmented crisis response; (ii) cooperation across municipalities and regions to minimise disjointed responses and competition for resources during and after the crisis; (iii) opportunities offered by digitalisation to support crisis management at all levels of government; (iv) continuous dialogue between national and subnational governments, regarding COVID-19's fiscal impact on subnational budgets using shared evidence and data, taking into account the differentiated impact of the crisis; ( $v$ ) introduction of other temporary or permanent fiscal tools and measures, including more flexible, modern and innovative financial management tools for more effective subnational finance management; (vi) stengthen national and subnational-level support for vulnerable groups to limit further deterioration in circumstances and to strengthen inclusiveness in the recovery phase; (vii) ease the administrative burden on core regional and local services and those that help small and medium enterprises, the self-employed and vulnerable populations; (viii) ensure that all levels of government should treat similar small and medium enterprises in the same way; (ix) use public investment at all levels of government to support recovery from COVID-19 over time.

Precisely in order to debate the territorial implications within the EU arising from the COVID-19 pandemic, Medeiros, Guillermo Ramírez, Ocskay and Peyrony (2020) analyze the territorial effects of ,covidfencing' and its effects on regions and on cross-border cooperation. Agnoletti, Manganelli and Piras (2020) analyzed Italy's rural landscape according to the intensity of energy inputs used in the agricultural process, socioeconomic and environmental features in order to understand the correlation between the number of COVID-19 infections and the different rural landscapes of the country. Arbolino and Di Caro (2020) studied the extent to which EU funds promote regional resilience at the time of COVID-19, taking into account the experience of the Great Recession.

The OECD defends the importance of considering 'adopting a place-based or territorially sensitive approach to exit-strategy implementation and recovery policies' (OECD, 2020b, p. 2) that should take into account the following aspects (OECD, 2020a, p. 3-17): (i) local responses matter for short-term and long-term impacts; (ii) the key challenge for local and regional actors will be to take into account the changes brought by the COVID-19 crisis to construct the communities of a new tomorrow; (iv) capitals and large cities often face a larger share of jobs potentially at risk than other regions in the same country; ( $v$ ) within a country, differences in the share of regional employment potentially at risk vary by more than 20 percentage points; (vi) beyond the direct employment effects, supply chain disruptions and the scaling back of global trade due to containment measures can also have diverse effects on regions, with places more integrated in global trade potentially hit the hardest; (vii) regions also vary considerably in the share of workers in non-standard employment that could be at greater risk; (viii) previous recessions have had long-term negative impacts on local labour markets, notably unemployment rates ${ }^{4}$; (ix) COVID-19 will likely accelerate automation, and some regions have more jobs at risk; $(x)$ national policies in response to COVID-19 that may appear uniform (or place-blind) are not place neutral and will affect communities differently; (xi) some populations will be more vulnerable to short-term job losses and long-term re-integra-

\footnotetext{
${ }^{4}$ Several years after the 2008 crisis, weaker local labour markets had a higher share of temporary work contracts (OECD, 2020a, p. 9).
} 
tion challenges. Low-skilled, low-wage, and young people may be the most vulnerable to job losses because they are in the sectors most at risk today; (xii) the social economy is a driver of job creation and economic activity with social impact, and is a powerful tool for local development to respond to the consequences of COVID-19; (xiii) small and medium enterprises account for around two-thirds of employment in OECD countries and the self-employed account for a further $15 \%$ of jobs and they are particularly vulnerable to the effects of coronavirus; (xiv) investments today in lifelong learning and vocational training can ensure workers are ready for the upturn, while also supporting regions to make transitions to new economic opportunities; (xv) increased teleworking, both within cities and in rural areas will create new challenges and opportunities; (xvi) increased pressure on digital infrastructure; (xvii) re-localisation of production; (xviii) the new restrictions on people's international movements.

In the RHOMOLO analysis, Conte, Lecca, Sakkas and Salotii (2020, p. 4) argue that the adverse shock is symmetric due to the global scale of the pandemic, as it hit all EU member states. However, its territorial effects vary in terms of magnitude due to the specific characteristics of the various regional economies of the EU. For instance, regions where jobs are largely concentrated in tourism-related services sectors will experience larger job disruptions.'

In Europe's moment: Repair and Prepare for the Next Generation, the European Commission (2020d, p. 2-3) argues that: (i) overall, the EU economy is expected to shrink by more than $7 \%$ in 2020; (ii) the initial recovery will be partial and the impact felt acutely by people and businesses; (iii) the economic impact of the crisis will differ greatly between different parts of the economy businesses providing client-facing services or relying on crowded workplaces and customer areas are most affected. Tourism, the social economy and the creative and cultural ecosystems could see a drop in turnover of more than $70 \%$ in the second quarter of 2020. Textile, transport, energy-intensive industries and the renewable energy sector will also be hit hard. Ecosystems with higher consumer confidence, such as manufacturing, retail or health are likely to bounce back faster, while others may face a delayed economic hit; (iv) the impact and recovery potential also depends on each country's demographic or economic structure, with for instance those with a high number of small and medium-sized enterprises hit harder. This also depends on their ability and capacity to absorb and respond to the shock.

Naturally, each of these sectoral and techno-productive situations affects all local and regional territories differently, precisely according to their economic, sectorial and demographic characteristics. Recognition of these different sensitivities and resilience conditions, both sectoral and territorial, to the impact of COVID-19 and the need to ensure territorial and sectorially differentiated policy responses is also present in some contemporary reports (e.g. Hurley, Fernández-Macías, Bisello, Vacas \& Fana, 2019; OECD, 2020c).

\section{Conclusions and recomendations}

The Barca Report (2009) defined the rationale for action for the EU's CP 2014-2020 and the placebased approach, which is one of its key foundations, in An Agenda for a Reformed Cohesion Policy. For Barca (2009, p. vii):

(...) a place-based policy is a long-term strategy aimed at tackling persistent underutilisation of potential and reducing persistent social exclusion in specific places through external interventions and multilevel governance. It promotes the supply of integrated goods and services tailored to contexts, and it triggers institutional changes. In a place-based policy, 
public interventions rely on local knowledge and are verifiable and submitted to scrutiny, while linkages among places are taken into account.

The analysis carried out reveals that the current pandemic context of COVID-19, due to its transversal impacts on the economy and society: (i) implies the redesign of many of the Union's public policy instruments and the creation of others specially designed to deal with the pandemic; (ii) reorders some of the EU's current strategic priorities; (iii) attributes a new relevance, on a European scale, to areas of public policy such as health and civil protection; (iv) changes the conditions of relative competitiveness of local and regional territories; $(v)$ reformulates the planning guidelines and assumptions underlying the definition of current and future development models of cities and regions, and (vi) reinforces the relevance of territorialized public policy instruments such as the place-based aprroach.

EU CP 2021-2027 continues to attach great importance to the need to ensure a more tailored approach to regional development and to supporting locally-led development strategies. Before the beginning of the COVID-19 pandemic, there was already a conviction that much of the future of the place-based approach in the EU context would depend, among other aspects, on (Neto, Serrano \& Santos, 2018, p. 14-16):

1. 'The relation of the post-2020 Cohesion Policy with the Union's new strategic priorities, in the fields of globalization, demography, migration, environment, climate change, security and defense, employment and digitalization of the economy and society. Because many of these new Cohesion Policy priorities will introduce new uncertainties and will generate new budgetary needs for the implementation of this policy, but also because those priorities will compete, in budgetary terms, with the priorities of a more "regional" nature";

2. The future options on the rationalization and revision of geographical and thematic objectives, and geographic scales and models of action, for the CP post-2020. In particular, concerning the future of the current policy instruments - Integrated Territorial Investments (ITI), Research and Innovation Strategies for Smart Specialisation (RIS3) and Community-led local development (CLLD) - and how they will support the territorialisation of public policies and the implementation of integrated territorial approaches;

3. The ambitioned evolution will lie in the nature of the process of territorialisation of public policies;

4. The future role of mega-regions in the context of the post-2020 CP;

5. To what extent RIS3 could be understood, in the post-2020 period, as instruments for rationalizing and aggregating other spatially more circumscribed integrated territorial approaches, such as ITI and CLLD;

6. The future of the multilevel governance approach;

7. The understanding of what will be, or should be, the next generation of RIS3.

Reflection and decision-making on these issues is even more necessary today, due to the different reasons presented throughout this article, many of them stemming from the effects of the COVID-19 pandemic and how to respond to it.

The Union's most recent policy instruments, namely the European Green Deal, the EU Digital Strategy, the EU Circular Ecomony Action Plan, the EU Annual Sustainable Growth Strategy, and the European strategy to implement the United Nations Sustainable Development Goals 2030, demand a territorialized vision and place-based implementation approaches that ensure expression in the development strategies of the EU's local and regional territories.

Completion of this new set of EU policy instruments would, in itself, justify review of the placebased approaches and the reformulation of mechanisms for the territorialisation of public policies in the EU context. All of the aspects described above should be understood as the structural ele- 
ments for the definition, within the framework of the EU and each of its member states, of a new political economy of local and regional territories in the EU post-2020.

\section{References}

Agnoletti, M., Manganelli, S., \& Piras, F. (2020). Covid-19 and rural landscape: The case of Italy. Landspace and Urban Planning, 204, 103955. https://doi.org/10.1016/j.landurbplan.2020.103955

AP (2018). Setting the Course for the future of Territorial and Urban Policies at European level. Background Paper for the DG Seminar on 13th November 2018, Vienna, under the Austrian EU Presidency. Retrieved from https://www.oerok.gv.at/fileadmin/user_upload/Bilder/2.Reiter-Raum_u._Region/4. Europ-Raumentwicklung/2019_Dokumente_EU_Ratsvorsitz/EU_Vorsitz_2018_zu_TA_UA_GD-Seminar_am_13-11-18_Background_Paper.pdf

Arborino, R., \& Di Caro, P. (2020). Can the EU funds promote regional resilience at time of Covid19? Insights from the Great Recession. Journal of Policy Modeling. https://doi.org/10.1016/j. jpolmod.2020.10.001

Barca, F. (2009). An Agenda For A Reformed Cohesion Policy.A place-based approach to meeting European Union challenges and expectations. Retrieved from https://ec.europa.eu/regional_policy/ archive/policy/future/pdf/report_barca_v0306.pdf

Barca, F., McCann, P., \& Rodríguez-Pose, A. (2012). The Case for Regional Development Intervention: Place-Based versus Place-Neutral Approaches. Journal of Regional Science, 52(1), 134-152. https:// doi.org/10.1111/j.1467-9787.2011.00756.x

Bentley, G., \& Puglis, L. (2014). Shifting paradigms: People-centred models, active regional development, space-blind policies and place-based approaches. Local Economy, 29(4-5), 283-294. https:// doi.org/10.1177/0269094214541355

Blomi, V., \& Erlich, M. (2020). On Optimal Design of Place Based Policies: A structural evaluation of EU regional transfers. Journal of International Economics, 125, 103319. https://doi.org/10.1016/j. jinteco.2020.103319

CEAP (2020). Additional tools. EU Circular Economy Action Plan. Retrieved from https://ec.europa.eu/ environment/circular-economy/

Celata, F., \& Coletti, R. (2014). Place-based strategies or territorial cooperation? Regional development in transnational perspective in Italy. Local Economy, 29(4-5), 394-411. https://doi. org/10.1177/0269094214533903

Ciampi Stancova, K. (2020). Science Technology and Innovation for Sustainable Development Goals: Smart Specialisation and transnational partnerships. Paper presented at SMARTER 2020 Conference Webinar Series - Conference on Smart Specialisation and Territorial Development: Connecting grand societal challenges with local goals in place-based innovation policy (10 November 2020). Retrived from https://s3platform.jrc.ec.europa.eu/-/smarter-2020-conference-3d-webinar-smart-specialisation-for-sustainable-development-goals?inheritRedirect=true

Conte, A., Lecca, P., Sakkas, S., \& Salotti, S. (2020). The territorial economic impact of COVID-19 in the EU. A RHOMOLO Analysis. Territorial Development Insights Series, JRC121261. Seville: European Commission. Retrieved from https://ec.europa.eu/jrc/sites/jrcsh/files/jrc121261.pdf

Council (2020). Special European Council, 17-21 July 2020. Retrieved from https://www.consilium. europa.eu/en/meetings/european-council/2020/07/17-21/

DS2019-2024 (2020). Priority. A Europe fit for the digital age. Retrieved from https://ec.europa.eu/info/ strategy/priorities-2019-2024/europe-fit-digital-age_en

EC (2018). European Commission Digital Strategy. A digitally transformed, user-focused and data-driven Commission. $\operatorname{COM(2018)~} 7118$ final. Brussels: European Commission.

EC (2019a). The European Green Deal. COM(2019) 640 final. Brussels: European Commission.

EC (2019b). Annual Sustainable Growth Strategy 2020. COM(2019) 650 final. Brussels: European Commission. 
EC (2020a). A new Circular Economy Action Plan For a cleaner and more competitive Europe. COM(2020) 98 final. Brussels: European Commission.

EC (2020b). 2020 European Semester: Spring Package. European Commission Retrieved from https:// ec.europa.eu/info/publications/2020-european-semester-spring-package_en

EC (2020c). 2020 European Semester: Country-specific recommendations. COM(2020) 500 final. Brussels: European Commission.

EC (2020d). Europe's moment: Repair and Prepare for the Next Generation. COM(2020) 456 final. Brussels: European Commission.

EC (2020e). Regional Development and Cohesion Policy beyond 2020: The New Framework at a glance. Retrieved from https://ec.europa.eu/regional_policy/en/2021_2027/

EC (2020f). The EU Budget Powering the Recovery Plan for Europe. Retrieved from https://ec.europa.eu/ info/sites/info/files/factsheet_1_en.pdf

EC (2020g). A European roadmap to lifting coronavirus containment measures. Retrieved from https:// ec.europa.eu/info/sites/info/files/factsheet-lifting-containment-measures_en.pdf

EC (2020h). Pan-European Hackathon: EU Vs Virus Challenge. Retrieved from https://ec.europa.eu/eip/ ageing/events/pan-european-hackathon-eu-vs-virus-challenge_en

EC (2020i). Commission presents European Skills Agenda for sustainable competitiveness, social fairness and resilience. Retrieved from https://ec.europa.eu/commission/presscorner/detail/en/IP_20_1196

EC (2020j). Cohesion policy action against coronavirus. Retrieved from https://ec.europa.eu/regional_ policy/en/newsroom/coronavirus-response/

EC (2020k). Europe's moment: Repair and prepare for the next generation. Retrieved from https://ec.europa.eu/commission/presscorner/detail/en/ip_20_940

EC (2020l). Fund for European Aid to the Most Deprived (FEAD). Retrieved from https://ec.europa.eu/ social/main.jsp?catld=1089\&langld=en

EC $(2020 \mathrm{~m})$. Cohesion Policy and EU Solidarity Fund contribute to the Coronavirus Response Investment Initiative. Retrieved from https://ec.europa.eu/regional_policy/en/newsroom/ news/2020/03/16-03-2020-cohesion-policy-and-eu-solidarity-fund-contribute-to-the-coronavirus-response-investment-initiative

EC (2020n). Coronavirus Response Investment Initiative Plus: New actions to mobilise essential investments and resources. Retrieved from https://ec.europa.eu/regional_policy/en/newsroom/ news/2020/04/04-02-2020-coronavirus-response-investment-initiative-plus-new-actions-to-mobilise-essential-investments-and-resources

EDS (2020). The European Digital Strategy. Retrieved from https://ec.europa.eu/digital-single-market/ en/content/european-digital-strategy

ESM (2020). ESM Pandemic Crisis Support. Retrieved from https://www.esm.europa.eu/content/ europe-response-corona-crisis

EU (2020). Re-open EU. Retrieved from https://reopen.europa.eu/

Eurostat (2020). Sustainable development in the European Union Monitoring report on progress towards the SDGs in an EU context. 2020 edition. Luxembourg: Publications Office of the European Union. https://doi.org/10.2785/555257

Gianelle, C., Guzzo, F., \& Mieszkowski, K. (2020). Smart Specialisation: what gets lost in translation from concept to practice? Regional Studies, 54(10), 1377-1388. https://doi.org/10.1080/00343404.2019 .1607970

Gianelle, C., Kyriakou, D., McCann, P., \& Morgan, K. (2020). Smart Specialisation on the move: reflections on six years of implementation and prospects for the future. Regional Studies, 54(10), 1323-1327. https://doi.org/10.1080/00343404.2020.1817364

Glaeser, E., \& Gottlieb, J. (2008). The Economics of Place-Making Policies. Brookings Papers on Economic Activity, 39(1), 155-253.

Guastella, G., \& Timpano, F. (2016). Knowledge, innovation, agglomeration and regional convergence in the EU: motivating place-based regional intervention. Review of Regional Research, 36, 121-143. https://doi.org/10.1007/s10037-015-0104-x 
Horlings, L. G., Roep, D., \& Wellbrock, W. (2018).The role of leadership in place-based development and building institutional Arrangements. Local Economy, 33(3), 245-268. https://doi. org/10.1177/0269094218763050

Hurley, J., Fernández-Macías, E., Bisello, M., Vacas, C., \& Fana, M. (2019). European Jobs Monitor 2019: Shifts in the employment structure at regional level. Luxembourg: Publications Office of the European Union. Retrieved from https://www.eurofound.europa.eu/publications/report/2019/ european-jobs-monitor-2019-shifts-in-the-employment-structure-at-regional-level

Jia, J., Ma, G., Qin, C., \& Wang, L. (2020). Place-based Policies, State-led Industrialisation and Regional Development: Evidence from China's Great Western Development Program. European Economic Review, 123, 103398 https://doi.org/10.1016/j.euroecorev.2020.103398

von der Leyen, U. (2019). A Union that strives for more. My agenda for Europe. Political Guidelines for the Next European Commission 2019-2024. Retrieved from https://ec.europa.eu/commission/sites/ beta-political/files/political-guidelines-next-commission_en.pdf

von der Leyen, U. (2019, November 2019). Speech in the European Parliament Plenary Session. Retrieved from https://ec.europa.eu/commission/presscorner/detail/pt/speech_19_6408

Logan, J. R., \& Molotch, H. L. (1987). Urban Fortunes: The Political Economy of Place. Berkeley, CA: The University of California Press.

Magro, E., \& Wilson, J. (2019). Policy-mix Evaluation: Governance Challenges from Placed-Based Innovation Policies. Research Policy, 48(10), 103612. https://doi.org/10.1016/j.respol.2018.06.010

McCann, P., \& Ortega-Argilés, P. (2016). Smart Specialisation: Insights from the EU Experience and Implications for Other Economies. Investigaciones Regionales - Journal of Regional Research, 36, 279-293.

Medeiros, E., Guillermo Ramírez, M., Ocskay, G., \& Peyrony, J. (2020). Covidfencing effects on cross-border deterritorialism: the case of Europe. European Planning Studies, 1-21. https://doi.org/10.1080 /09654313.2020.1818185

Morgan, K., \& Jones, I. R. (2019). Foundational economy (as if people and places really matter). Presentation at UK2070 Commission: Wales Stakeholder Event (14 June 2019). Retrived from https:// wiserd.ac.uk/news/foundational-economy-presentation-uk2070-commission-event

Neto, P. (1999). A Integração Espacial, Economias de Rede e Inovação [Spatial Integration, Network Economies and Innovation]. Lisboa: Instituto Piaget.

Neto, P. (2020a). O Orçamento de Estado para 2020 e as Políticas Públicas. Presentation at Conferência no âmbito da 15a Conferência Anual da Ordem dos Economistas, 'O Orçamento de Estado para 2020' (15 January 2020).

Neto, P. (2020b). Bringing People Back to the Center of Public Policies. Economic and Political Dynamics Emerging from the Covid-19 Pandemic. Paper presented at International Colloquium on Politics and Pandemics: transdisciplinary views on dilemmas of the Earthly City (4-6 November 2020).

Neto, P., \& Santos, A. (2020). Guidelines for Territorial Impact Assessment applied to Regional Research and Innovation Strategies for Smart Specialisation. In E., Medeiros (Ed.). Territorial Impact Assessment (pp. 211-230). Berlin: Springer.

Neto, P., Serrano, M. M., \& Santos, A. (2018). Renewed challenges for public policies in post-2020 Cohesion Policy: From RIS3 to RIS4 and a new social dimension for smart specialisation. Public Policy Portuguese Journal, 3(1), 8-26.

Neumark, D., \& Simpson, H. (2015). Place-Based Policies. In G., Duraton, J. V., Henderson \& W., Strange (Eds.). Handbook of Regional and Urban Economics (vol. 5, pp. 1197-1287). Amsterdam: Elsevier.

OECD (2020a). From Pandemic to Recovery: Local employment and economic development. OECD Tackling Coronavirus (COVID-19): Contributing to a Global Effort. Paris: OECD Publishing. Retrieved from http://www.oecd.org/coronavirus/policy-responses/from-pandemic-to-recovery-local-employment-and-economic-development-879d2913/

OECD (2020b). The Territorial Impact of COVID-19: Managing the crisis across levels of governments. OECD Tackling Coronavirus (COVID-19): Contributing to a Global Effort. Paris: OECD Publishing. Retrieved from http://www.oecd.org/coronavirus/policy-responses/the-territorial-impact-of-covid19-managing-the-crisis-across-levels-of-government-d3e314e1/ 
OECD (2020c). OECD Employment Outlook 2020: Worker Security and the COVID-19 Crisis. Paris: OECD Publishing. https://doi.org/10.1787/1686c758-en

Partridge, M. D., Rickman, D. S., Rose Olfert, M., \& Tan, Y. (2013). When Spatial Equilibrium Fails: Is Place-Based Policy Second Best? Regional Studies, 49(8), 1303-1325. https://doi.org/10.1080/003 43404.2013.837999

TA2030 (2020). Territorial Agenda 2030. A future for all places. Retrieved from https://www.territorialagenda.eu/home.html

TA2030A (2020). Actions putting the Territorial Agenda into practice. Retrieved from https://www.territorialagenda.eu/actions.html

Tomaney, J. (2010). Place-Based Approaches to Regional Development: Global Trends and Australian Implications. Sydney: Australian Business Foundation. Retrived from http://alstonvillewollongbar. com.au/members/Library/Documentation/2014/Place_based_competitiveness_australia.pdf

Trippl, M., Zukauskaite, E., \& Healy, A. (2020). Shaping smart specialization: the role of place-specific factors in advanced, intermediate and less-developed European regions. Regional Studies, 54(10), 1328-1340. https://doi.org/10.1080/00343404.2019.1582763

Varga, A. (2017). Place-based, Spatially Blind, or Both? Challenges in Estimating the Impacts of Modern Development Policies: The Case of the GMR Policy Impact Modeling Approach. International Regional Science Review, 40(1), 12-37. https://doi.org/10.1177/0160017615571587

Veldhuizen, C. (2020). Smart Specialisation as a Transition Management Framework: Driving sustainability-focused regional innovation policy? Research Policy, 49(6), 103982. https://doi.org/10.1016/j. respol.2020.103982 